\title{
Finnish Straight-A Graduates' Perceptions of the Smoothness of their Study Paths
}

\author{
Mari Salmela (Corresponding author) \\ University of Lapland \\ PO Box 112, 96101 Rovaniemi, Finland \\ Tel: 358-50-349-9173_E-mail: msalmela@ulapland.fi \\ Satu Uusiautti \\ University of Lapland \\ PO Box 112, 96101 Rovaniemi, Finland \\ Tel: 358-40-484-4167Ｅ-mail: satu@uusiautti.fi
}

Received: Sep. 1, 2013 Accepted: September 21, 2013 Published: November 1, 2013

doi:10.5296/jse.v3i4.4270 URL: http://dx.doi.org/10.5296/jse.v3i4.4270

\begin{abstract}
The purpose of this study is to discuss the smoothness of the study paths by describing Finnish general upper secondary education graduates' study paths: What factors have promoted and supported straight-A graduates' study paths? What kind of difficulties have straight-A graduates' faced in their study paths? This was a narrative study conducted in 2012 by collecting straight-A graduates' writings $(\mathrm{N}=14)$. The data were analyzed with narrative analyzing methods. The results showed the multidimensional nature of study paths: there is not just one way of reaching the same outcome. When it came the smoothness of study paths, it appeared that also the success-oriented students need support and guidance with their choices, goals, and strengths.
\end{abstract}

Keywords: Upper secondary education, Students, Graduates, Matriculation examination, Narrative research 


\section{Introduction}

In Finland, students continue their studies after the comprehensive school in general upper secondary education or vocational upper secondary education: the former provides with a qualification to apply for university-level education, while the latter prepares in a profession and/or provides a qualification for polytechnics and universities of applied sciences. About $60-70 \%$ of the youth graduates from general upper secondary education. Most of them are girls (60\%) (Rinne, 2007). The age group covers mainly 15-19-year-old youngsters (Laitinen, 2012). Finnish general upper secondary education has liberal arts and trains for the final exam called matriculation examination. The main task of the general upper secondary education is to provide students with preparedness to continue studies at universities, polytechnics, or in vocational education (Finnish National Board of Education, 2003). Law on General Upper Secondary Education (1998/629) dictates that general upper secondary education should also support students' life-long learning skills.

The nature of general upper secondary education varies not only internationally (see e.g., Klainin \& Fensham, 2006; Nagy et al., 2006; Neild, Stoner-Eby, \& Furstenberg, 2008) but also among the Nordic Countries (Erikson \& Rudolphi, 2010; Wikström \& Wikström, 2005) due to differences in education policies and systems. National and local solutions, time allocation of school subjects, the number of obligatory and optional subjects, the names of subjects and their contents, and the total number of study hours in the whole general upper secondary education vary greatly (Tuijula, 2011). For example, compared to the American education system, the Finnish general upper secondary education (see the Education System of Finland at http://www.minedu.fi/export/sites/default/OPM/Koulutus/koulutusjaerjestelmae /liitteet/finnish_education.pdf) seems to be equivalent with secondary education, especially senior high school education (see U.S. Network for Education Information, 2007).

In addition to qualification to university-level studies, the Finnish general upper secondary education provides readiness to meet the societal and environmental challenges and analyze phenomena from various perspectives. Students learn to recognize inconsistencies between pronounced values and the reality, and to critically reflect on the deficits and opportunities of the Finnish society and international development. Students will also familiarize themselves with the citizens' basic rights in Finland, the Nordic Countries, and European Union, and what the rights mean in practice and how they are maintained and furthered. Furthermore, general upper secondary education provides skills to face the challenges of the changing world, supports the development of students' self-knowledge and favorable growth to adulthood, and encourages students to life-long learning and development. Students are considered the builders of their own learning, expertise, and world-views (Finnish National Board of Education, 2003).

The Finnish general upper secondary education is a continuum of the syllabus of basic education and lasts for three years. Students can finish their studies faster or slower if they want to but the studies can last four years maximum (Finnish National Board of Education, 2012). Studies end with the matriculation examination which is a nation-wide final exam and an essential force in the Finnish society. Not only provides the successful passing of the exam 
eligibility to higher education studies but it also is a continuous and important means of evaluating general upper secondary education. The matriculation examination guarantees consistent evaluation and it is also used as a central tool of student selection at universities and polytechnics (Matriculation Examination Board, 2012b).

The exam is held twice a year and at the same time in all Finnish general upper secondary education schools. Students can take the test at once or during three consecutive test times: the matriculation examination includes at least four separate tests in the Finnish language and literature and in three optional school subjects (Finnish National Board of Education, 2012). Students can also take additional tests in subjects they prefer (Law on General Upper Secondary Education, 1998/629). On average, Finnish students take tests in roughly five subjects (Matriculation Examination Board, 2012b).

The Matriculation Examination Board is chosen by the Ministry of Education and Culture for a three-year period and this board is responsible for the matriculation examination, design of tests, and student evaluation. The matriculation examination is scored with the following grades (from highest to lowest): laudatur (L), eximia cum laude approbatur (E), magna cum laude approbatur (M), cum laude approbatur (C), lubenter approbatur (B), and approbatur (A), and improbatur (I) which means fail. The proportions of grades are kept somewhat the same from year to year so that the best $5 \%$ of students gets laudatur in each test (Matriculation Examination Board, 2012a). To become a graduate, students have to pass the general upper secondary education studies and the examination-so it is not enough to pass just the matriculation examination. Every year about 30,000 students graduate from general upper secondary education, and 40-104 of them scores at least six subjects with laudatur yearly (Matriculation Examination Board, 2012a).

The purpose of this research was to describe the study paths of the most successful graduates of the Finnish general upper secondary education: what factors have promoted and supported the straight-A students' study paths and what kind of difficulties they have had? This theme is very important to all today's students, their parents and teachers, and the whole school system as the purpose is to discuss how to support and enhance the smooth studies and natural transitions from an education level to another and to working life.

\section{Theoretical Background: Studies on Smooth Study Paths in Upper Secondary Education Level}

Regardless of the differences in education systems, upper secondary level education makes an important phase in studies and in the course of life. Those who do well in general upper secondary education may have known already at elementary school that they will continue in general upper secondary education after basic school (Olkinuora et al., 2007) while even some of the general upper secondary education students do not have any idea what they will do or study in the future (Anttila, 2013; Salmela-Aro, 2011). Balancing between the demands of general upper secondary education and one's own resources can lead to committed studying or fatigue. While commitment and drive predict successful transition to higher education and further one's chances of graduating in time, perceived fatigue in general upper secondary education makes all this difficult and is connected with prolonged studies as well 
(Geiser \& Santelices, 2007; Hickman et al., 2008; Salmela-Aro, 2011; Warburton, Bugarin, \& Nuñez, 2001). Indeed, Finnish educationalists have expressed their concern over the prolonged general upper secondary education studies: belated graduation predicts the same in higher education and shorter periods of employment (Klemelä et al., 2007; Salmela-Aro, 2011).

The smoothness of study paths at upper secondary level education has been studied abundantly in Finland and abroad. The phenomenon itself is wide and can be studied from various perspectives: For example, studies have focused on the family background including the social status of family and its connection with students' choices and studies (Carvalho \& Novo, 2012; Gouvias, Katsis, \& Limakopoulou, 2012; Norberg-Schonfeldt, 2008; Rinne, 2007; Walkerdine, Lucey, \& Melody, 2001; Warburton et al., 2001; cf. Baker, 2009). Likewise, research has shown that students' self-efficacy (e.g., Bandura, 1997; Lane \& Lane, 2001; Hsieh, Sullivan, \& Guerra, 2007; Weiser \& Riggio, 2010), study motivation (Areepattamannil, 2012), developed self-regulation (e.g., Tuijula, 2011; Zimmerman, 1990), and optimistic thinking and action (e.g., Hoy, Tarter, \& Woolholk Hoy, 2006; Nonis \& Wright, 2003) have a clear connection with the smoothness of upper secondary education studies. Learning-oriented students emphasize the mastery of learning new things and contents when referring to their school-related aspirations. This is related to the sense of finding studies meaningful, the commitment of education goals, and well-being (Tuominen-Soini, 2012; see also Green et al., 2012). According to Anttila (2013), general upper secondary education students often find the development of study and thinking skills more important than learning the contents of school subjects. Completing studies is seen as a manifestation of self-efficacy, and the black-and-white student's cap is the symbolic sign of it.

The smoothness of study paths is also studied from the points of view of stress and school fatigue (Liu \& Lu, 2011; Ollfors \& Andersson, 2007; Salmela-Aro, 2011). Success-oriented students pursue learning, are committed to studying, and do well at school. On the other hand, the endeavor for success is also connected with the fear of failure and susceptibility to problems in well-being, such as stress and fatigue (Tuominen-Soini, 2012). There are also comparative studies between graduates and drop-outs and their developmental school paths (Barrington \& Hendricks, 1989; Ehrenreich et al., 2012; Hickman et al., 2008; Matute-Bianchi, 1986; Jimerson, Anderson, \& Whipple, 2002; Osborne \& Walker, 2006; Stearns \& Glennie, 2006). Studies have found out that both the aforementioned are developmental processes, and not just singular events (Alexander, Entwisle, \& Horsey, 1997; Garnier, Stein, \& Jacobs, 1997; Jimerson, Anderson, \& Whipple, 2002).

\section{Method}

The purpose of the research was to describe the study paths in the light of the narratives of Finnish straight-A general upper secondary education graduates. In this study, the concept of straight-A student refers to a student who has gotten at least six laudatur grades from the matriculation examination. They represent a minority of their age group and thus, form a special group among Finnish graduates.

The following research question was set for this study: What are Finnish straight-A graduates’ 
study paths like? This question was studied through the sub-questions of

(1) What factors have promoted and supported straight-A graduates' study paths?

(2) What kind of difficulties have straight-A graduates' faced in their study paths?

Furthermore, the purpose of the study is to analyze the special nature of these study paths in the light of the graduates' narratives.

The study employed the narrative research approach which was considered a suitable means of looking for answers to the research questions. This approach formed the meta-theoretical basis of the research and the way knowing and the nature of knowledge was understood. People perceive, interpret, and construct the surrounding world through narratives (Bruner, 1986; 1990). Therefore, narratives can be seen as the fundamental way of knowing and constructing one's self. Furthermore, narrative research can refer to the nature of the research data, data collection methods, and data analyses (Lieblich, Tuval-Mashiach, \& Zilber, 1998; Polkinghorne, 1995).

The data collection started in summer 2012 by sending by mail a request to write an essay to 19 straight-A graduates. The participants had to fulfill the following selection criteria: they had have had graduated from general upper secondary education schools in 2010-2012 with at least six laudatur grades. 14 graduates replied to the request by sending their written narratives. 11 of them were women and three men. The low number of men can be partly explained by the fact that women tend to perform better than men in the matriculation examination (Matriculation Examination Board, 2012a).

The participants were given directions how to write essays. They were asked to write about the top moments of their study paths and about the most significant experiences of success and knowing. They were also asked to talk about adversities and difficulties, factors that had hindered the smoothness of study paths. In addition, the graduates were asked to write about their study paths starting from the elementary education all to way to the matriculation examination and to complete the goal of becoming a straight-A graduate. The narratives appeared rich and profound reports of the straight-A graduates' school years and events along their study paths (see Peura, 2008). The narratives were from two to 15 sheets long, and thus, the total length of data was 75.5 pages.

The research data were analyzed according to the principles of narrative analyses but the analysis also resembled traditional qualitative content analysis. First, the analysis was focused on the contents of the written narratives (what the story is about), in other words, what the straight-A graduates tell about their study paths while the form of the narratives (how the story is told) was given the backseat (Chase 2008; Riessman 2008; Holstein \& Gubrium 2012).

On the other hand, the analysis followed Polkinghorne's (1995) division between analysis of narratives and narrative analysis. Analysis of narratives aims at categorizing the data with various metaphors and categories. Narrative analysis organizes the data into a coherent and chronological plot, a new narrative which can be called a meta-narrative. This study applied 
these both types of narrative analyses.

Third, narrative analysis also involved features of categorical-content analysis and holistic-form analysis (Lieblich, Tuval-Mashiach, \& Zilber, 1998) as the purpose of analysis was to find common features, themes, differences, and regularities in the graduates' narratives in addition to produce new narratives.

When it comes to the reliability of the study, it is relevant to ask to what extent the pre-structured request to write about school paths influenced the contents of the narratives. Basically at its purest, narrative research means answering to just one question asking to describe the process or phenomenon studied (Riessman, 2008; Hatch \& Wisniewski, 1995). However, the purpose of the request was only to give idea of the theme that graduates were asked to write about. The instructions left contentual choices to the participants: they decided where they would start, which events, experiences, feelings, and people they would include in the narrative. What was considered the most valuable feature of the data was the events and issues the graduates themselves considered worth talking about and including in their narratives.

Naturally in narrative research, the lifelikeliness and verisimilitude of the narratives can be evaluated (Bruner, 1986). This means that it is not necessary to prove whether the events described by the participants actually happened but to have as life-like narratives as possible. The purpose is to open the straight-A graduates' world in a way that the reader can understand their choices, action, and motives.

\section{Results}

The following results section consists of three chapters: the factors that the graduates had found supportive and enhancing, and the difficulties and adversities are introduced as the results of the analysis of narratives. They are followed by four meta-narratives that form the results of narrative analysis.

\subsection{Supportive and enhancing factors along the study paths}

The straight-A graduates named several factors and events that had furthered and supported their studies. One of the most salient ones was their own curiosity and constant interest in surrounding happenings (see also Peterson \& Park, 2011):

"The simple fact that I am so curious and thirsting for knowledge has helped me considerably both at school and in life otherwise, too.”

The narratives described how curiosity and interest fostered intrinsic motivation to focus on and work for one's goals. Indeed, this kind of behavior has a verifiable connection with such educational goals that cannot be reached without great effort (Ratelle et al., 2007; Smith, Ntoumanis, \& Duda, 2007; Vasalampi, 2012).

In addition to their personal features, the straight-A graduates recognized the role of their home. On the one hand, their homes had provided them with the feeling of safety and secured childhood, on the other hand, their parents had been supportive and interested in their 
development and success. While parents had emphasized the importance of school and learning, they had not pressured the graduates or demanded "top scores", according to the graduates' narratives. Instead, their parents had also "tried to calm down the pursuit of A's" by emphasizing that "school is for life, not for grades." These results are in line with the findings that parents' support and commitment enhance the smoothness of their children's study paths and success at school (Christenson \& Anderson, 2002; Epstein \& Sheldon, 2002; Reschly \& Christenson, 2009).

Peer relationship appeared the third most significant factor in the graduates' school paths. The importance of these relationships were described for example as follows:

"The social life was probably one of the most important things at the general upper secondary education school, it kept me in my senses, and these friends still are important in my life.”

When moving from childhood into adolescence, the role of family as the centrum of social relationships diminishes when the young start to choose their social environments. Friends and other people they have found become significant alongside with their families (e.g., Carr, 2011). Seven straight-A graduates described how the meaning of the circle of friends became especially highlighted in upper secondary education. They had found like-minded people who also appreciated schooling and studying from the school.

"My circle of friends had, of course, very positive attitudes to school and looked for future studies, as well."

On one hand, the graduates' stories described how the youth look for companionship and solidarity, and ways of reflecting on their own lives and sharing the common phase of life. On the other hand, the narratives also reveal how important the positive peer relationships and shared experiences are for the smoothness of study paths as they support the subjective well-being and school contentment of the youth (see also Doll et al., 2009; Elffers, Oort, \& Karsten, 2012; Wentzel, Baker, \& Russel, 2009; Wang \& Eccles, 2012).

In addition, nine participants of this study brought out the importance of hobbies. Hobbies provided them with resources, and a way of relaxing and "forget about worries and stress." The other contribution of hobbies was that they taught "time management and tolerance of disappointments, and keep one's head under exam situations.” Hobbies also taught "how to bear responsibility for one's doings" and "were useful in versatile ways in different school subjects.” According to the graduates' perceptions, a good hobby is not only a way of relieving stress but also a way of developing oneself, increasing one's skills, and expanding and maintaining social relationships.

The teacher's role was also discussed in graduates' essays. Nine of them acknowledged that teachers "deserve indescribable big thanks for being a salient part of the success." The graduates considered it important that "the teacher gets the students feel themselves important and clever human beings, and they can affect success at school by their attitudes and teaching." Teachers were expected to provide "both sufficient encouragement and support and reasonable demands and obligations." This made the graduates want to show teachers what they can achieve. "A strict and demanding but fair” teacher could spur students to 
achievements that "one could not think of being able to reach." The teacher-student relationship appeared as one of the most significant factors directing the smoothness of study paths and school success (see also Doll et al., 2009). This is in line with the notion that students are satisfied when teachers consider them as developing individuals with personal strengths (Fredrickson, 2001; Wentzel, 2002).

The sixth factor mentioned by half of the participants was trips to abroad either as an exchange student or living there with their families and going to a foreign school. Time spent abroad strengthened their language skills and taught and offered "more careless, more social" way of living and "a breathing space from school."

\subsection{Factors hindering the smoothness of study path}

The graduates were asked to describe adversities and difficulties they had had along their study paths. In all, they found fewer of these than the positive factors, partly because of the fact that they found it difficult to "remember any major trouble from the school path because there was not any”. The most central difficulty concerned conflict situations in peer relationships and being afraid of failure.

Seven straight-A graduates described conflicts related to peer relationships. This was natural because, as the previous chapter showed, friendships were considered an important support at school. Simultaneously, they involved a flip side: "Standing out from the crowd is not an advantage" because "at the certain phase of study path, some peers find doing well at school anything else than great." Therefore, "status as a straight-A student” was sometimes hard to bear and "getting always A's" put pressure also on relationships with peers. One of the graduates described how "sometimes, the thought of having less than an A from an exam was almost scary: would the classmates make a fuss of it?” One graduate described this worry concretely: "If someone got a better grade [than I did], students could snipe at me sometimes for weeks." The experiences of being a sort of super-human were common to another graduate too. Probably, no one had even thought of making friends with the straight-A students: "I cannot remember if anyone asked me to join evening gatherings outside school ever?" Sniping and isolation along the years gnawed away self-esteem to the extent that it became "hard to believe it is true, if someone wants to make friends because of your personality and not so much because of the school success.”

Worry over one's failure was common among straight-A graduates. Half of them reported how "ambition or merely fear of failure was always present in studies." Losing or failing was never an option. One of the graduates described how "every grade really had to an A." At school, A's were paralleled with one's value as a person but with other's acceptance, too. Another graduate wrote how the constant effort of surprising and exceling oneself and others led to a situation in which studies took so much time that the graduate had to give up all hobbies.

Some of the graduates saw even the smallest failure as a big lost. Indeed, the endeavor of perfect success was evident in the data. This behavior was described as follows:

"Wrong answers in tests or lessons have haunted me for a long time." 
"I get easily depressed if I fail in something, and I often blame myself for it."

Perfectionism and fear of failure could cause considerable stress. One of the graduates told of being "so nervous that I started to grind my teeth at nights and woke up with aching jaws and teeth. I felt a lump in my throat the whole day and churning almost all the time.” Another graduate reported of sleeping problems, and three graduates had extended their perfectionism into control over their eating.

\subsection{Narrative analysis: Four paths of becoming a straight-A graduate}

Narrative analysis combines the narratives that comprised the data in this study. Although each narrative was one-of-a-kind, it was possible to find similar features from the study paths. The following sections will introduce the result of the narrative analysis: four meta-narratives of straight-A graduates' study paths.

\subsubsection{An Independent Study Path}

The straight-A graduate was anxiously waiting to start school. She had learned to read by herself long before school would start. The first school years were partly frustrating: others were practicing syllables and spelling from an ABC book while the graduate already read non-fiction books and Harry Potter at home. However, she enjoyed being at school and the whole elementary education was just fun stay when it came to studying. During the first school years, the graduate did not have any specific goals or expectations. She just simply wanted to know as much as possible. As numeral evaluations began at school, the goals started to be clear and only A's were good enough.

The graduate considered herself similar to her peers at elementary school, although one of the best students. But every class has those couple "swots". At secondary school, it became clear that she was really talented. The difference to her classmates was at its highest then. Standing out from the crowd was not always an advantage because some students did not think high of school success at that education level. The straight-A graduate was taunted, even bullied. However, she could separate these experiences from studies and focused on finding the joy from positive things. She also enjoyed various hobbies. Adversities taught how to be herself openly.

The beginning of general upper secondary education was a significant turning point. That was the best time of the graduate's school path. These studies were challenging, something that the graduate had longed for. In addition, vigorous study rhythm felt good. She also found like-minded peers who could appreciate success at school. Nevertheless, the straight-A graduate needed independency and possibility to work alone. She felt that she was the happiest and most efficient learner when she could determine where and how she would study. She did not need any directions and was capable of making her own decisions. She also flinched from the study techniques taught at student counseling lessons. Instead, she read as much and as hard as needed to get an A, and "that's it".

The school was important to the graduate. It was an environment in which she could realize her expertise in the best possible way and develop in something she was interested in. She 
experienced the most important successes at school. When the matriculation examination was topical, she was satisfied: she had reached what she had pursued and what she felt residing with her.

\subsubsection{School Path as a Pursuit of Perfection}

The thought of going to school brought butterflies to the straight-A graduate's tummy, she could barely wait for the school to begin. She had been very curious already as a small child always willing to learn new things. She also liked challenges and exploring. Since the very first grade at school, the straight-A graduate considered it obvious that homework was always done and she would always prepare for exams properly. She did not like failures, and wrong answers in exams or lessons could occupy one's mind for a long time. Therefore, it was important to prepare and do homework well, and always do one's best in order to avoid blaming oneself for lack of trying. The straight-A graduate was aware of the fact that she got plenty of excellent grades, results that no one else could achieve. She did not, however, consider it an exceptional talent but a result of hard work, diligence, and self-discipline sometimes even luck.

Going to secondary education is a tough phase for the straight-A graduate. The friends from elementary school go to different classes and thus the circle of friends is broken. The new school seems cheerless and strange. The study style suits the graduate better than the one used in elementary education. She has always enjoyed writing and exams started to have questions that had to answered by essays. Yet, the team spirit, friends, and peers were gone, and therefore, the straight-A graduate started to focus more on her grades and surpassing herself.

The pursuit for perfection was at its highest when the straight-A graduate went to the general upper secondary education. She really wanted to have just A's. Concern over failure was sometimes so gnawing that she had sleeping problems and other stress symptoms. Her coping was tested. Despite all the stress and pressure, the straight-A graduate felt enormous joy of learning almost in every school subject. None of them were too difficult, or at least they were able to learn with hard work and guts. Little by little the grades lost their importance as the graduate started to discover her innermost. Everything related to school was interesting: she loved to write, and learn languages and about foreign cultures, history, and math. During her last study year, she could even have fun every now and then which is a considerable change to the previous. She could find the joy and strength from music and sport, and writing about her own thoughts, feelings, and experiences. Moreover, she found a few friends who had unspeakable significance for her school success and mental coping.

After the Matriculation Examination, the straight-A graduate noted that the school had had a big role in her life, sometimes even so big that she had let that define her self and human worth. However, the all-or-nothing attitude she had adopted during her school years had helped her to achieve things she had wanted but it had also taught her about her own limits and to accept them. After the Matriculation Examination, she thought that it had been worth it. 


\subsubsection{Study Path with the Emphasis on Human Relationships}

Already from the very first school day, the straight-A graduate loved the atmosphere at school. She liked reading and writing and the smell of new books. She had no trouble whatsoever to learn and acquire new things: she learned fast and easily, relatively effortlessly. Along her school years, at the general upper secondary school at the latest, the straight-A graduate realized that she was really and truly good at school and could excel herself. In addition, she noticed that her goals were higher than her school mates' goals.

However, the best memories of school did not concern the school and studying itself but the social life at school. The graduate had always felt quite shy. At school, she got to know new people. Having new friends was the best in her life. She could remember thousands of moments of laughing aloud and spending time with peer students. Especially, at general upper secondary school, her circle of friends expanded considerably. She found the best, like-minded company that she could not have even had dreamed of. The team spirit at the school was great as a whole. She was surrounded by peers and teachers who encouraged and motivated her to succeed at school and with whom she could genuinely share the moments of success. No one considered her as a freak but she was known as a person who always got A's and knew the answers. In addition to her peer relationships, her family and parents supported her significantly. She felt that she could live her adolescence in a careless and safe environment. Sharing school-related joys and worries daily with parents was important.

The role of school was quite big in her life and she also spend plenty of time there after school days just by hanging around with her friends. She was actively organizing various theme days and parties at school or representing her school by playing whatever sports in interscholastic tournaments. Hobbies were important too. They provided the graduate with important skills such as patience and responsibility. However, primarily hobbies functioned as a counterbalance to studies. After the Matriculation Examination, the straight-A graduate concluded that time spent at school was a top period of her life.

\subsubsection{School as Work}

Freedom and carelessness typified the straight-A graduate's first school years. At elementary school, she was not very studious with homework but tended to finish them in the nick of time. However, she did them relatively diligently and in time, as well as the graduate could. She could have improved the appearance of her notebooks and handwriting but she did not want to waste time with them. She was more interested in various plays and ball games, exploring things, and reading books. At elementary and secondary school, she only wanted to have fair grades. She was successful because she was good at concentrating during lessons. Of course, she might have been a little bit talented too.

At the general upper secondary school, the straight-A graduate started to realize the importance of education. She choose as widely as possible subjects that she was especially interested in and invested in those ones she thought would be useful when applying for higher education. The goal was to study so that she would not have any regrets in the future. Yet, she did not aim at any higher grades than she would need to get in the school she wanted to after 
the upper secondary education.

The surrounding relationships at home and school, and in leisure, each supported her study path. At home and school, the importance of studying was emphasized but her parents and teachers did not set any pressure at her. Various circles of friends and hobbies supported her study path by offering counterbalance and distance to school. Friends also encouraged her to relax. Indeed, her studies passed without any greater difficulties despite the fact that some periods at school were actually quite hard leaving little time for relaxation. Stress and work load taxed sometimes and caused fatigue. This did not bring down the graduate but she just persistently worked and finished each period at a time.

The school and studies had quite important position in the straight-A graduate's study path. Her everyday life was not, however, very school oriented but school was one part of her life: school was work.

\section{Discussion}

In Finland, the position of general upper secondary education has been the most popular study path after basic education for several decades (Olkinuora et al., 2007). The youth still respect the matriculation examination although vocational upper secondary education has increased its popularity (Koistinen, 2010) while the general upper secondary education is perceived demanding and time consuming (Klemelä et al., 2007).

The narratives of the Finnish straight-A graduates revealed how study paths form a part of the course of life, including both uphill and downhill, turns and straights. Every student has his or her own goals that direct the study path and its smoothness (see also Anttila, 2013). One finds it important to get higher education while someone else wants to have just straight A's. Someone prefers independency in studies while another finds social relationships the most important (see Locke, 2002). In other words, while someone can consider general upper secondary education important for further goals, some other enjoys general upper secondary education as such (Olkinuora et al., 2007). Therefore, the student self through all his or her goals and expectations has a significant role in the smoothness of a study path (Carver \& Scheier, 2002). In order to achieve the goals, the student has to direct his or her action and ponder what he or she wants and why, what kind of goals to set and how to achieve them. The student also has to prioritize and handle possible difficulties and obstacles (Locke, 2002).

The smoothness of straight-A graduate's study paths can be viewed from the point of view of the SOC model, launched by Baltes and Freund (2003). The model starts with the idea of three fundamental processes of positive development: selection, optimization, and compensation. Thus, smoothness of a study path can mean that the student can choose subjects that correspond to his or her skills and strengths (see also Määttä \& Uusiautti, 2012). Selection gives a direction to the study path by focusing the resources on certain areas and regulating behavior from a situation and time to another (Baltes \& Freund, 2003). Optimization refers to a process in which the student chooses the most suitable and relevant study methods (Määttä \& Uusiautti, 2012). It is a process in which relevant means or resources are acquired, refined, coordinated, and applied (Baltes \& Freund, 2003). 
Compensation means the use of optional means in order to maintain certain functional level when old methods are found useless or dysfunctional (Baltes \& Freund, 2003). In other words, the student should be ready to try optional subjects and study methods that could enhance the smoothness of the study path. This necessitates that the student should constantly and consciously evaluate new situations, and his or her possibilities and skills (see Määttä \& Uusiautti, 2012; San Antonio, 2008).

The straight-A graduates' narratives showed how important it is that students can choose school subjects that support their strengths and study methods that suit them. While some students prefer independent learning and the freedom of choosing how and when they study, some others like regularity and clear directions that guide their learning. And again, some students can find social study methods and forms the most suitable.

The straight-A graduate's study paths also revealed that they cannot be viewed separate from their environment (see Huebner, Gilman, \& Furlong, 2009; Magnusson \& Mahoney, 2003; Pedrotti, Edwards, \& Lopez, 2009). In addition to aforementioned student-specific factors, goals and expectations, study paths involve peer relationships, family life, encouraging teachers, interesting hobbies, and relaxing free time (see Lowe \& Gayle, 2007). Moreover, the student's self-image of himself or herself as a learner is constructed in interaction with the surrounding people and culture: general upper secondary education students' study paths are holistic so that the smoothness of each study path is always more than the sum of its parts (Magnusson \& Mahoney, 2003). The individual student develops and acts as an active part of the system created by the personality and environment and that is open to changes for the whole life span. Every level of the individual-environment system gets its typical features from the mutual interaction between its elements, not just from the influence of the separate parts.

Määttä and Uusiautti (2012) have concluded that students' study paths are guided by four core factors. The student himself or herself including his or her abilities, habits, motivation, study skills, and preconceptions, forms one of these four core factors. In addition to student-specific factors, various institutional features, such as the institutional atmosphere and student culture, teachers and their teaching skills and pedagogical qualification, curricula, have influence on the smoothness of study paths (see also Zhao \& Kuh, 2004).

The results also showed that not even straight-A graduates can avoid difficulties and adversities - they belong to everyone's life (Larsen et al., 2003). However, they can lead to important experiences of success and self-discovery (see Peura, 2008). Of course, the perceived level of difficulties varies individually, but what was common to the graduates in this research was that their mentioned conflicts in peer relationships and concern of their own failure. Some graduates had traveled their study paths longing for peer support and sense of solidarity (cf., Green et al., 2001; Hodges et al., 1999), while some others preferred independent work. How hard or depressing the lack of peer support was perceived depended on whether it was a voluntary choice or not (see also Vaarala, Uusiautti, \& Määttä, 2013).

Difficulties in straight-A graduates study paths also brought out the feature that is unique among top students like they are. Success at school is not just sunshine but can become an 
enormous burden. The results showed that some had descended into the path of compulsive performing and succeeding instead of learning new things. Worry and anxiety were complemented with feelings of fear and tension. Success could be pursued even in the expense of peer relationships (e.g., Tuominen-Soini, 2012).

The fact that none of the straight-A students regretted their study paths was a crucial observation, as well. Eventually, they were all content because they had survived from years of hard studying and the matriculation examination (see Peura, 2008). Thus, further research on the smoothness of study paths should be focused on the individual who functions and develops as an active and intentional part of the personality-environment system (Magnusson \& Mahoney, 2003) and how these could be created.

\section{Conclusion}

When evaluating this research and its reliability, it is worth discussing the extent the analyzing methods do violence to the data through categorizations and classifications. Graduates’ personal narratives were first categorized into factors enhancing and hindering the smoothness of the study path, and then they were squeezed into four narratives. Inevitably, it was impossible to bring out all special features, nor did each narrative purely represent one of the four meta-narratives. Instead, every narrative had features of these four metanarratives: some just resembled more for example independent paths while others had more similar features with the narrative of school as work. Therefore, it is not relevant whether a certain graduate would represent perfectionist or not but the point of this kind of analysis is to illustrate the variations of study paths leading to the same outcome. In addition, the narratives were written from a certain time perspective: the graduates had graduated just a little while ago, and therefore, the narratives extend only to the moment of graduating with at least six subjects with laudatur. However, the analysis showed the unique nature of the graduates' study paths: the phenomenon of the smoothness of study paths consists of the synergy of many factors. It is also worth pointing out that the narratives are not comparable: there are not any right or wrong path. Instead, it is reasonable to consider what can be learned from these results and what the crucial points of straight-A graduates' study paths are.

In all, the smoothness of study path is a sum of individual and outer factors. Everyone has school-related goals that direct their study paths. However, not only goals (Anderman \& Anderman, 2009) but also the quality of motivation matter. Likewise, the study showed that the environment, including its opportunities, limitations, and challenges, can have a crucial role in the smoothness of study paths. While most students need support from for example parents and teachers for finding one's strengths and interests, this study showed that also the success-oriented straight-A students need special support and guidance.

\section{Acknowledgement}

The research is financed by Finnish Cultural Foundation.

\section{References}

Alexander, K. A., Entwisle, D. R., \& Horsey, C. S. (1997). From first grade forward: Early 
foundations of high school dropout. Sociology of Education, 70(2), 87-107. http://dx.doi/org/10.2307/2673158

Anderman, L. H., \& Anderman E. M. (2009). Oriented towards mastery. In R. Gilman, E. S. Huebner, \& M. J. Furlong (Eds.), Handbook of positive psychology in schools (pp. 161-173). New York, NY: Routledge.

Anttila, T. (2013). "Vaikka en lakkia saisikaan, niin olenpahan jotain oppinut” [”Even though I did not graduate, I have learned something”]. (PhD Diss., University of Lapland, Rovaniemi, Finland).

Areepattamannil, S. (2012). Mediational role of academic motivation in the association between school self-concept and school achievement among Indian adolescents in Canada and India. Social Psychology of Education: An International Journal, 15(3), 367-386. http://dx.doi.org/10.1007/s11218-012-9187-1

Baker, J. G. (2009). Class, ability, mobility: Economic and academic paths from middle school to early adulthood. Journal of Education Finance, 34(4), 355-371.

Baltes, P. B., \& Freund, A. M. (2003). Human strengths as the orchestrations of wisdom and selective optimization with compensation. In L. G. Aspinwall \& U. M. Staudinger (Eds.), A psychology of human strengths. Fundamental questions and future directions for a positive psychology (pp. 25-35). Washington, DC: American Psychological Association.

Bandura, A. (1997). Self-efficacy: The exercise of control. New York, NY: W. H. Freeman.

Barrington, B. L., \& Hendricks, B. (1989). Differentiating characteristics of high school graduates, dropouts and non-graduates. The Journal of Educational Research, 82, 309-319.

Bruner, J. (1986). Actual minds, possible worlds. Cambridge: Harvard UP.

Bruner, J. (1990). Acts of meaning. Cambridge: Cambridge University Press.

Carr, A. (2011). Positive psychology. The science of happiness and human strengths. (2nd ed.) London: Routledge.

Carvalho, R. G., \& Novo, R. F. (2012). Family socioeconomic status and student adaptation to school life: Looking beyond grades. Electronic Journal of Research in Educational Psychology, 10(3), 1209-1222.

Carver, C. S., \& Scheier, M. F. (2002). Optimism. In C. R. Snyder \& S. J. Lopez (Eds.), Handbook of positive psychology (pp. 231-243). Oxford: Oxford University Press.

Chase, S. (2008). Narrative inquiry: Multiple lenses, approaches, voices. In N. K. Denzin \& Y. S. Lincoln (Eds.), Collecting and interpreting qualitative materials (pp. 57-94). (3rd ed.) London: Sage.

Christenson, S. L., \& Anderson, A. R. (2002). The centrality of the learning context for students' academic enabler skills. School Psychology Review, 31, 378-393.

Doll, B., Kurien, S., Leclair, C., Spies, R., Champion, A., \& Osborn, A. (2009). The 
ClassMaps Survey. A framework for promoting positive classroom environments. In R. Gilman, E. S. Huebner, \& M. J. Furlong (Eds.), Handbook of positive psychology in schools (pp. 213-227). New York, NY: Routledge.

Ehrenreich, H., Reeves, P. M., Corley, S., \& Orpinas, P. (2012). With graduation in sight: Perceptions of high- and low-aggression students of the journey to high school completion. School Psychology Quarterly, 27(4), 198-209. http://dx.doi.org/10.1037/spq0000006

Elffers, L., Oort, F. J., \& Karsten, S. (2012). Making the connection: The role of social and academic school experiences in students' emotional engagement with school in post-secondary vocational education. Learning and Individual Differences, 22(2), 242-250. http://dx.doi.org/10.1016/j.lindif.2011.08.005

Epstein, J. L., \& Sheldon, S. B. (2002). Present and accounted for: improving student attendance through family and community involvement. Journal of Educational Research, 95, 308-318. http://dx.doi.org/10.1080/00220670209596604

Erikson, R., \& Rudolphi, F. (2010). Change in social selection to upper secondary school primary and secondary effects in Sweden. European Sociological Review, 26(3), 291-305. http://dx.doi.org/10.1093/esr/jcp022

Finnish National Board of Education. (2003). Lukion opetussuunnitelman perusteet 2003 [The core curriculum for general upper secondary education 2003]. Helsinki: Finnish National Board of Education.

Finnish National Board of Education. (2012). Koulutusopas 2013. Ammatillinen koulutus ja lukiokoulutus sekä vapaa sivistystyö [Education guide 2013. Vocational and general upper secondary education and commercial education]. Helsinki: Finnish National Board of Education.

Fredrickson, B. L. (2001). The role of positive emotions in positive psychology: The broaden-and-build theory of positive emotions. American Psychologist, 56, 218-226. http://dx.doi.org/10.1037/0003-066X.56.3.218

Garnier, H. E., Stein, J. A., \& Jacobs, J. K. (1997). The process of dropping out of high school: A 19-year perspective. American Educational Research Journal, 34, 395-419. http://dx.doi.org/10.3102/00028312034002395

Gouvias, D., Katsis, A., \& Limakopoulou, A. (2012). School achievement and family background in Greece: a new exploration of an omnipresent relationship. International Studies in Sociology of Education, 22(2), 125-145.

Green, J., Liem G. A., Martin, A. J., Colmar, S., Marsh, H. W., \& McInerney, D. (2012). Academic motivation, self-concept, engagement and performance in high school: key processes from a longitudinal perspective. Journal of Adolescence, 35(5), 1111-1122. http://dx.doi.org/10.1016/j.adolescence.2012.02.016

Green, L. R., Richardson, D. S., Lago, T., \& Schatten-Jones, E. C. (2001). Network correlates of social and emotional loneliness in young and older adults. Personality and Social 
Psychology Bulletin, 27(3), 281-288. http://dx.doi.org/10.1177/0146167201273002

Hatch, J. A., \& Wisniewski, R. (1995). Life history and narrative: questions, issues and exemplary works. In J. A. Hatch \& R. Wisniewski (Eds.), Life history and narrative (pp. 113-135). London: Falmer.

Hickman, G. P., Bartholomew, M., Mathwig, J., \& Heinrich, R. S. (2008). Differential developmental pathways of high school dropouts and graduates. The Journal of Educational Research, 102(1), 3-14. http://dx.doi.org/10.3200/JOER.102.1.3-14

Hodges, E. V., Boivin, M., Vitaro, F., \& Bukowski, W. M. (1999). The power of friendship: Protection against an escalating cycle of peer victimization. Developmental Psychology, 35, 94-101.

Holstein, J. A., \& Gubrium, J. F. (2012). Varieties of narrative analysis. London: Sage.

Hoy, W. K., Tarter, C. J., \& Woolfolk Hoy, A. (2006). Academic optimism of schools: a force for student achievement. American Educational Research Journal, 43(3), 425-446. http://dx.doi.org/10.3102/00028312043003425

Hsieh, P., Sullivan, J. R., \& Guerra, N. S. (2007). A closer look at college students: self-efficacy and goal orientation. Journal of Advanced Academics, 18(3), 454-476.

Huebner, E. S., Gilman, R., \& Furlong, M. J. (2009). A conceptual model for research in positive psychology in children and youth. In R. Gilman, E. S. Huebner, \& M. J. Furlong (Eds.), Handbook of positive psychology in schools (pp. 3-8). New York, NY: Routledge.

Jimerson, S. R., Anderson, G. E., \& Whipple, A. D. (2002). Winning the battle and losing the war: examining the relation between grade retention and dropping out of high school. Psychology in the Schools, 39(4), 441-457. http://dx.doi.org/10.1002/pits.10046

Klainin, S., \& Fensham, P. J. (2006). Learning achievement in upper secondary school chemistry in Thailand: some remarkable sex reversals. International Journal of Science Education, 9(2), 217-227. http://dx.doi.org/10.1080/0950069870090210

Klemelä, K., Tuittu, A., Olkinuora, E., Rinne, R., Leppänen, R., \& Aro, K. (2007). Muuttuva lukio tutkimuskohteena [The changing general upper secondary education as a research target]. In K. Klemelä, E. Olkinuora, R. Rinne, \& A. Virta (Eds.), Lukio nuorten opiskelutienä. Turkulainen lukio opiskelijoiden, vanhempien ja opettajien silmin 2000-luvun alussa [General upper secondary education as the study path of the youth] (pp. 11-38). Turku: University of Turku.

Koistinen, M. (2010). Nuorten hyvinvointi, opiskelu ja opinto-ohjaus erityisen koulutustehtävän saaneessa lukiossa [Youngsters' well-being, studies, and study councelling in a general upper secondary education school with a special education task]. Helsinki: University of Helsinki.

Laitinen, L. (2012). Onnelliset opintiellä? Lukiolaisten hyvinvointitutkimus 2012 [The happy on the study path? Survey of well-being among the general upper secondary education 
students 2012]. Helsinki: Suomen Lukiolaisten Liitto.

Lane, J., \& Lane, A. (2001). Self-efficacy and academic performance. Social Behavior and Personality, 29, 687-694.

Larsen, J. F., Hemenover, S. H., Norris, C. J., \& Cacioppo, J. T. (2003). Turning adversity to advantage. On the virtues of the coactivation of positive and negative emotions. In L. G. Aspinwall \& U. M. Staudinger (Eds.), A psychology of human strengths. Fundamental questions and future directions for a positive psychology (pp. 211-226). Washington, DC: American Psychological Association.

Law on General Upper Secondary Education. (1998/629). Helsinki: Ministry of Justice. Retrieved from the Finlex data base: http://www.finlex.fi/fi/laki/smur/1998/19980629

Lieblich, A., Tuval-Mashiach, R., \& Zilber, T. (1998). Narrative research: reading, analysis and interpretation. London: Sage.

Liu, Y., \& Lu, Z. (2011). The Chinese high school student's stress in the school and academic achievement. Educational Psychology, 27-35. http://dx.doi.org/10.1080/01443410.2010.513959

Locke, E. A. (2002). Setting goals for life and happiness. In C. R. Snyder \& S. J. Lopez (Eds.), Handbook of positive psychology (pp. 299-312). Oxford: Oxford University Press.

Lowe, J., \& Gayle, V. (2007). Exploring the work/life/study balance: The experience of higher education students in a Scottish further education college. Journal of Further and Higher Education, 31(3), 225-238. http://dx.doi.org/10.1080/03098770701424942

Magnusson, D., \& Mahoney, J. L. (2003). A holistic person approach for research on positive development. In L. G. Aspinwall \& U. M. Staudinger (Eds.), A psychology of human strengths: Fundamental questions and future directions for a positive psychology (pp. 227-244). Washington, DC: American Psychological Association.

Matriculation Examination Board. (2012a). Ylioppilastutkinto 2011. Tilastoja ylioppilastutkinnosta [Matriculation Examination 2011. Information about Matriculation Examination]. Helsinki: Matriculation Examination Board.

Matriculation Examination Board. (2012b). Ylioppilastutkintolautakunnan toimintakertomus 2012 [The annual report of Matriculation Examination Board]. Helsinki: Matriculation Examination Board.

Matute-Bianchi, M. E. (1986). Ethnic identities and pattern of school success and failure among Mexican-Descent and Japanese-American students in a California High School: an ethnographic analysis. American Journal of Education, 95(1), 233-255. http://dx.doi.org/10.1086/444298

Ministry of Education and Culture. Education System of Finland. Retrieved from: http://www.minedu.fi/export/sites/default/OPM/Koulutus/koulutusjaerjestelmae/liitteet/finnis h_education.pdf. 
Määttä, K., \& Uusiautti, S. (2012). How to enhance the smoothness of university students' study paths? International Journal of Research Studies in Education, 1(1), 47-60. http://dx.doi.org/10.5861/ijrse.2012.v1i1.16

Nagy, G., Trautwein, U., Baumert, J., Köller, O., \& Garret, J. (2006). Gender and course selection in upper secondary education: effects of academic self-concept and intrinsic value. Educational Research and Evaluation: An International Journal on Theory and Practice, 12(4), 323-345. http://dx.doi.org/10.1080/13803610600765687

Neild, R. C., Stoner-Eby, S., \& Furstenberg, F. (2008). Connecting entrance and departure. The transition to ninth grade and high school dropout. Education and Urban Society, 40(5), 543-569. http://dx.doi.org/10.1177/0013124508316438

Nonis, S. A., \& Wright, D. (2003). Moderating effects of achievement striving and situational optimism on the relationship between ability and performance outcomes of college students. Research in Higher Education, 44(3), 327-346. http://dx.doi.org/10.1023/A:1023029815944

Norberg-Schonfeldt, M. (2008). Children's school achievement and parental work: An analysis for Sweden. Education Economics, 16(1), 1-17. http://dx.doi.org/10.1080/09645290701273525

Olkinuora, E., Tuittu, A, Klemelä, K., Leppänen, R., \& Aro, K. (2007). Lukiossa opiskelu opiskelijoiden näkökulmasta [Studies at general upper secondary education from students' perspective]. In K. Klemelä, E. Olkinuora, R. Rinne, \& A. Virta (Eds.), Lukio nuorten opiskelutienä. Turkulainen lukio opiskelijoiden, vanhempien ja opettajien silmin 2000-luvun alussa [The general upper secondary education school as the study path of the youth] (pp. 41-122). Turku: University of Turku.

Ollfors, M., \& Andersson, S. I. (2007). Ability of stress, sense of control and self-theories to predict Swedish high school students' final grades. Educational Research and Evaluation, 13(2), 143-169. http://dx.doi.org/10.1080/13803610701434241

Osborne, J. W., \& Walker, C. (2006). Stereotype threat, identification with academics and withdrawal from school: why the most successful students of colour might be most likely to withdraw. Educational Psychology: An International Journal of Experimental Educational Psychology, 26(4), 563-577. http://dx.doi.org/10.1080/01443410500342518

Pedrotti, J. T., Edwards, L. M., \& Lopez, S. J. (2009). Positive psychology within a cultural context. In S. J. Lopez \& C. R. Snyder (Eds.), The Oxford handbook of positive psychology (pp. 49 - 58). 2nd edition. Oxford: Oxford University Press.

Peterson, C., \& Park, N. (2011). Character strengths and virtues: Their role in well-being. In S. I. Donaldson, M. Csikszentmihalyi \& J. Nakamura (Eds.), Applied positive psychology. Improving everyday life, health, schools, work and society (pp. 49-62). New York, NY: Psychology Press.

Peura, A. (2008). Tohtoriksi tulemisen tarina [Narrative of becoming a doctor]. Helsinki: University of Helsinki. 
Polkinghorne, D. (1995). Narrative configuration in qualitative analysis. In J. A. Hatch \& R. Wisniewski (Eds.), Life history and narrative (pp. 5-23). London: Falmer.

Ratelle, C. F., Guay, F., Vallerand, R. J., Larose, S., \& Sénécal, C. (2007). Autonomous, controlled and amotivated types of academic motivation: A person-oriented analysis. Journal of Educational Psychology, 99, 734-746. http://dx.doi.org/10.1037/0022-0663.99.4.734

Reschly, A. L., \& Christenson, S. L. (2009). Parents as essential partners for fostering students' learning outcomes. In R. Gilman, E. S. Huebner, \& M. J. Furlong (Eds.), Handbook of positive psychology in schools (pp. 257-272). New York, NY: Routledge.

Riessman, C. K. (2008). Narrative methods for the human sciences. London: Sage.

Rinne, R. (2007). Lukionkäynti vanhempien näkemänä [General upper secondary education from the parents' perspective]. In K. Klemelä, E. Olkinuora, R. Rinne, \& A. Virta (Eds.), Lukio nuorten opiskelutienä. Turkulainen lukio opiskelijoiden, vanhempien ja opettajien silmin 2000-luvun alussa [General upper secondary education as the study path of the youth] (pp. 207-260). Turku: University of Turku.

Salmela-Aro, K. (2011). Mikä nuoria liikuttaa? Uupumuksesta intoon [What motivates the youth? From fatigue to enthusiam]. Tieteessä tapahtuu, 29(4-5), 3-6.

San Antonio, D. M. (2008). Understanding students' strengths and struggles. Educational Leadership, Apr/2008, 74-79.

Smith, A., Ntoumanis, N., \& Duda, J. (2007). Goal striving, goal attainment and well-being: Adapting and testing the self-concordance model in sport. Journal of Sport \& Exercise Psychology, 29, 763-782.

Stearns, E., \& Glennie, E. J. (2006). When and why dropouts leave high school? Youth \& Society, 38(1), 29-57. http://dx.doi.org/10.1177/0044118X05282764

Tuijula, T. (2011). "Jos tietää mitä haluaa": seurantatutkimus lukio-opiskelijoiden itsesäätelystä, opiskelun kulusta ja odotusten toteutumisesta ["If you know what you want": A follow-up study of general upper secondary education students self-regulation, study paths, and fulfilment of expectations]. Turku: University of Turku.

Tuominen-Soini, H. (2012). Student motivation and well-being. Achievement goal orientation profiles, temporal stability and academic and socio-emotional outcomes. Helsinki: University of Helsinki.

U.S. Network for Education Information. (2007). Organization of U.S. Education. Retrieved from:

http://www2.ed.gov/about/offices/list/ous/international/usnei/us/edlite-structure-us.html.

Vaarala, M., Uusiautti, S., \& Määttä, K. (2013). College students’ experiences of and coping with loneliness-possibilities of peer support. International Journal of Research Studies in Education, in press.

Vasalampi, K. (2012). Appraisals of education-related goals during educational transitions in 
late adolescence. Consequences for academic well-being and goal attainment. Jyväskylä: University of Jyväskylä.

Walkerdine, V., Lucey, H., \& Melody, J. (2001). Growing up girl - psychosocial explorations of gender and class. London: Palgrave.

Wang, M.-T., \& Eccles, J. S. (2012). Social support matters: Longitudinal effects of social support on three dimensions of school engagement from middle to high school. Child Development, 83(3), 877-895. http://dx.doi.org/10.1111/j.1467-8624.2012.01745.x

Warburton, E. C., Bugarin, R., \& Nuñez, A.-M. (2001). Bridging the gap: academic preparation and postsecondary success of first-generation students. Education Statistics Quarterly, 3(3), 73-77.

Weiser, D. A., \& Riggio, H. R. (2010). Family background and academic achievement: does self-efficacy mediate outcomes? Social Psychology of Education, 13, 367-383. http://dx.doi.org/10.1007/s11218-010-9115-1

Wentzel, K. R. (2002). Are effective teachers like good parents? Teaching styles and student adjustment in early adolescence. Child Development, 73, 287-301. http://dx.doi.org/10.1111/1467-8624.00406

Wentzel, K., Baker, S., \& Russel, S. (2009). Peer relationships and positive adjustment at School. In R. Gilman, E. S. Huebner, \& M. J. Furlong (Eds.), Handbook of positive psychology in schools (pp. 229-243). New York, NY: Routledge.

Wikström, C., \& Wikström, M. (2005). Grade inflation and school competition: an empirical analysis based on the Swedish upper secondary schools. Economics of Education Review, 24(3), 309-322. http://dx.doi.org/10.1016/j.econedurev.2004.04.010

Zhao, C. M., \& Kuh, G. D. (2004). Adding value: learning communities and student engagement. Research in Higher Education, 45(2), 115-138. http://dx.doi.org/10.1023/B:RIHE.0000015692.88534.de

Zimmerman, B. J. (1990). Self-regulated learning and academic achievement: an overview. Educational Psychologist, 25(1), 3-17. http://dx.doi.org/10.1080/00461520.2013.794676

\section{Copyright Disclaimer}

Copyright reserved by the author(s).

This article is an open-access article distributed under the terms and conditions of the Creative Commons Attribution license (http://creativecommons.org/licenses/by/3.0/). 